\title{
Physicochemical and microbiological evaluation of antioxidant-rich traditional black carrot beverage: Kanji
}

\author{
Chetna Sharma*, Param Pal Sahota and Sarabjit Kaur
}

\begin{abstract}
Background: Daucus carota subsp. sativus (Black carrots) are underutilized in context to their nutritional properties. In this study, Kanji, a naturally fermented probiotic beverage, was prepared using Daucus carota subsp. sativus (var. Punjab Black Beauty). Analysis of the physicochemical and microbiological profile of the naturally fermented Kanji was investigated to boost its utilization for commercial purpose.

Results: The physicochemical parameters observed in the fermented Kanji beverage were $\mathrm{pH} 3.47$, total soluble solids $3^{\circ} \mathrm{B}$, lactic acid $0.99 \%$, total sugars $36.32 \mathrm{mg} / \mathrm{mL}$, total reducing sugars $27.16 \mathrm{mg} / \mathrm{mL}$, flavonoids $38.14 \mathrm{mg} / \mathrm{mL}$, phenols $40.8 \mathrm{mg} / \mathrm{mL}$, antioxidant activity $79.96 \%$ and ascorbic acid $110 \mathrm{mg} / 100 \mathrm{~mL}$. The microbiological analysis revealed an exponential increase in lactic acid bacterial count from 3.96 to $8.33 \mathrm{log}$ CFU/mL. Out of 11 bacterial strains isolated from Kanji, the bacterial strain with high growth potential was genotypically characterized as Pediococcus acidilactici with accession number MK028218.
\end{abstract}

Conclusion: The lactic acid bacterial Kanji beverage was characterized as a potential plant-based probiotic with high antioxidant activity. This functional autochthonous starter from the Kanji can be used for selective fermentation of black carrots for Kanji ascertaining its microbiological safety, unique flavor and aroma, and consumption as a commercial non-dairy-based probiotic beverage.

Keywords: Black carrots, Fermentation, Functional foods, Lactic acid bacteria, Nutraceuticals, Pediococcus

\section{Background}

Fermentation, from the ages, serves as a food processing method harnessing microorganisms, primarily lactic acid bacteria (LAB), and yeast. In contrast with their unfermented counterparts, consumers prefer fermented products because of their characteristic aroma, texture, taste, and color (Rice-Evans et al. 1997). Probiotic food products are in concatenation with such foods and are viable selective microbial dietary supplements provided in an appropriate amount to bestow health benefits apart from the general nutrition. The impact on human health by probiotic lactic acid fermented foods has been promptly

*Correspondence: chetnasharma905@gmail.com

Department of Microbiology, Punjab Agricultural University, Ludhiana,

Punjab 141004, India suggested by health and medical professionals (Perricone et al. 2010). Probiotics, by definition, are "viable single or mixed bacterial preparation which, when provided to the host, benefits them by enhancing the properties of the gut flora" (In't Veld et al. 1994). Probiotics are required to be taken regularly in adequate doses $\left(\geq 10^{6} \mathrm{CFU} / \mathrm{mL}\right.$ daily) to avoid washout and ensuring the benefits are acquired in a sustained manner.

Most probiotic foods were constricted to dairy products but nowadays, plant-based fermented products are being increasingly considered as vectors for probiotic delivery (Soccol et al. 2010). Significant number of lactose intolerant people, higher cholesterol levels of dairy foods, and pronounced economic reasons in various 
developing countries necessitate the seek out for the alternatives with higher nutritive value along with healthpromoting factors, e.g., vegetables, fruits, cereals, and legumes, etc. (Perricone et al. 2010) and from products which have lower cholesterol content nevertheless rich in protein, starch, minerals, fibres, vitamins, and antioxidant contents. Besides this, with the popularism of vegetarian diets in both developed and developing countries, the demand for plant-based probiotics has elevated significantly. A large number of non-dairy-based traditionally fermented products are consumed all over the globe. However, these products have not been exploited commercially as probiotic beverages due to a lack of required scientific research. Plant-based fermented products are preferred on account of their bioactive properties along with their wholesome nutrient profile and unique taste and flavor.

Anthocyanin-rich black carrots (Daucus carota subsp. sativus) cultivated mainly in Northern India are utilized in the preparation of the lactic acid fermented probiotic beverage 'Kanji' by spontaneous fermentation of uniformly grated black carrots with requisite condiments concentration. Black carrots are in the focus due to their high anthocyanin content and extraordinary quality parameters (Kirca et al. 2006). Kanji beverage exhibits diuretic, digestive tract soothing, hepatoprotective, and uterine stimulating potential. The major anthocyanins in these carrots are derived from the acylation of cyanidins (Rice-Evans et al. 1997) and have greater color stability at food $\mathrm{pH}$ in contrast to the other anthocyanin sources of plant origin. Studies also suggest that LAB strains from Kanji showed their potential as probiotics and showed acid-bile salt tolerance, cholesterol assimilation, and antimicrobial activity against food-borne pathogens (Lamba et al. 2019). The identified strains were K1a: Lactobacillus curvatus, Lactobacillus delbrueckii, and K23c: Lactobacillus coryniformis (Reddy et al. 2007). Furthermore, Lactobacillus plantarum isolated from Kanjika was evaluated as a potential source of Vitamin B12 (Madhu et al. 2010).

The autochthonous $\mathrm{LAB}$ varies as a function of the quality of the raw material, harvesting conditions, and temperature. It was shown that the use of a starter culture helps to standardize the fermentation by controlling the microbial flora (Font de Valdez et al. 1990). This study was undertaken to study the nutritional profile of Kanji beverage and the isolation and characterization of the lactic acid cultures (LAB) present during fermentation from their natural environment. This study can be the basis for the development of potential starter cultures with predictable characteristics which can be used for commercial production of Kanji with consistent quality and good nutritive profile.

\section{Methods}

\section{Fermentation process}

Black carrots (Daucus carota subsp. sativus) of variety Punjab Black Beauty were procured from the Department of Vegetable Sciences, PAU, Ludhiana, Punjab, India. Common salt and rye as adjuvants were purchased from the local market, Ludhiana, Punjab. Fresh black carrots $(3 \mathrm{~kg})$ were washed with lukewarm water containing $0.01 \%$ potassium metabisulfite (KMS) solution for surface sterilization. The calyx was removed and carrots were aseptically lightly peeled. $3 \mathrm{~L}$ of boiled and then cooled bacteriologically safe water was added to $1 \mathrm{~L}$ of black carrot juice. Condiments salt and rye $(60 \mathrm{~g}$ each) were added to the fermenter after roasting them in the microwave oven at 800 watts for $1 \mathrm{~min}$. No starter culture was added as natural autochthonous flora was allowed for the spontaneous fermentation of the Kanji beverage. Fermentation of black carrot beverage was allowed at room temperature (RT) for five days which ensures the establishment of lactic acid bacteria in the beverage and reduces the risk of contamination. The naturally fermented Kanji beverage was stored at RT for six months in sterilized glass bottles. The bottles were sterilized by autoclaving. Microbiological and physicochemical analyses were performed at an interval of 20 days.

\section{Microbiological analysis of naturally fermented Kanji}

The traditionally fermented Kanji samples were diluted serially in $0.9 \%$ autoclaved saline and inoculated onto de Man Rogosa and Sharpe (MRS) agar plates and were incubated at $37^{\circ} \mathrm{C}$ for $24-48 \mathrm{~h}$ for total lactic acid bacterial counts. For the count of total mesophilic aerobic bacteria (TMAB), plate count agar was used with incubation at $37^{\circ} \mathrm{C}$ for $24-48 \mathrm{~h}$. Enumeration of total yeast count was performed using potato dextrose agar and plates were incubated at $28{ }^{\circ} \mathrm{C}$ for three days. The total coliform count was performed by sample enumeration on crystal violet neutral red bile lactose agar (VRBL agar) at $37^{\circ} \mathrm{C}$ for $24-48 \mathrm{~h}$.

\section{Biochemical and genotypic characterization of bacterial strains}

The biochemical and phenotypic characteristics of the lactic acid strains were compared with the previously published data for the identification of the cultures. Bacterial isolate with high growth potential was further analyzed by molecular characterization. After isolating Genomic DNA using the Schubert method (Schubert et al. 2008), the forward and reverse primers 27F ( $5^{\prime} \mathrm{AGA}$ GTTTGATCMTGGCTCAG3') and 1492R (5'TACGGY TACCTTGTTACGACTT3') were used in the amplification of the $16 \mathrm{~S}$ gene. The PCR reaction was carried out in $100 \mu \mathrm{L}$ volume $(10 \mu \mathrm{L} 10 \times$ PCR buffer, $2.5 \mu \mathrm{L}$ dNTPs 
mix, $2.5 \mu \mathrm{L}$ each primer, $1 \mu \mathrm{L}$ Taq DNA polymerase) with $3 \mu \mathrm{L}$ DNA template. The PCR cycle (Peltier Thermal Cycler, BIORAD) was conducted with the following program: $95^{\circ} \mathrm{C}$ for $5 \mathrm{~min}, 30$ cycles of $1 \mathrm{~min}$ at $95^{\circ} \mathrm{C}$, $1 \mathrm{~min}$ at $55^{\circ} \mathrm{C}, 1 \mathrm{~min}$ at $72^{\circ}$ and $5 \mathrm{~min}$ at $72{ }^{\circ} \mathrm{C}$. The PCR products were resolved by gel electrophoresis using $1.5 \%$ agarose gel and visualized by ethidium bromide staining. These PCR products were sent to a sequencing company for identification (Eurofins Genomics India Pvt Ltd, Karnataka, India) and the $16 \mathrm{~S}$ rDNA sequences were compared with known sequences in Genbank using BLAST (http://www.ncbi.nlm.nih.gov/blast). The 16S rRNA gene sequences have been submitted to NCBI GenBank Database.

Physicochemical analysis of naturally fermented Kanji $\mathrm{pH}$, titrable acidity (TA), total soluble solids (TSS), and sugar

\section{Antioxidant activity (\%) by DPPH assay}

$\%$ Antioxidant activity was measured by DPPH method (Brand-Williams et al. 1995). For estimation, a $100 \mu \mathrm{L}$ sample was taken and $3.9 \mathrm{~mL}$ DPPH solution $(1 \mu \mathrm{M}$ DPPH) was added afterward. Samples were placed in the dark for $45 \mathrm{~min}$. Discoloration in the solution was measured at wavelength $515 \mathrm{~nm}$ using Bausch \& Laumb Spectronic-20. Ascorbic acid was used as the standard for the calculations. \% Antioxidant activity was calculated by the formula given below:

$$
\% \text { Antioxidant Activity }=\left[1-\frac{\text { Absorbance of sample }}{\text { Absorbance of standard }}\right] \times 100
$$

\section{Ascorbic acid content}

2, 6-Dichlorophenol indophenol dye titration method was used in the estimation of ascorbic acid (AOVC 1996). Ascorbic acid content was calculated by the given formula:

$$
\mathrm{mg} \text { of Ascorbic acid } / 100 \mathrm{ml}=\frac{\text { Titre value } \times \text { Dye factor } \times \text { Volume made }}{\text { Aliquot taken } \times \text { Weight of sample }} \times 100
$$

\section{content}

$\mathrm{pH}$ and TA were analyzed according to standard protocols (AOAC 1984). TSS was measured by Erma hand Refractometer of $0-32^{\circ} \mathrm{Brix}$ (UNICO). Total sugars and reducing sugars were measured using Dubois et al. (1956) and Miller (Lamba et al. 2019) method, respectively.

\section{Flavonoids and phenols content}

Flavonoids (mg Quercetin equivalents) were evaluated by the method given by Chang et al. (2002) with small modifications. An aliquot of $200 \mu \mathrm{L}$ of each sample was taken to make up the final $1 \mathrm{~mL}$ volume using methanol. $100 \mu \mathrm{L} 10 \%$ aluminium nitrate solution was then added to each test tube. Then, $100 \mu \mathrm{L}$ of $1 \mathrm{M}$ potassium acetate was added followed by the addition of $4.6 \mathrm{~mL}$ distilled water. All samples were vortexed thoroughly and kept at room temperature for $45 \mathrm{~min}$. Finally, the absorbance $\left(\mathrm{OD}_{415}\right)$ was measured against a reference blank prepared in methanol.

Phenol content (mg Gallic acid equivalents) was investigated by the method of Singleton and Slinkard (1977) with slight modifications. $200 \mu \mathrm{L}$ of each sample/ standard was taken and $1 \mathrm{~mL}$ volume was made using methanol. Then, $2 \mathrm{~mL}$ of diluted Folin-ciocalteu reagent (1:9) was added and the contents were mixed thoroughly. $2 \mathrm{~mL}$ of $15 \% \mathrm{Na}_{2} \mathrm{CO}_{3}$ solution was added after 4 min and was kept at RT for $2 \mathrm{~h}$. In the end, the absorbance $\left(\mathrm{OD}_{760}\right)$ of the samples was measured.

\section{Statistical analysis}

The experiment was performed in triplicates. The data shown are means $( \pm$ SEM) of triplicates for each observation. The data were analyzed by one-way ANOVA in completely randomized design (CRD) using SAS software, version 9.4. Tukey's multiple comparison test $(\alpha=0.05)$ was used for examining significant differences between various observations.

\section{Results}

Enumeration of microorganisms in fermented Kanji

Viable microbial counts analyzed in the Kanji beverage during six months are shown in Fig. 1. Total viable bacterial and LAB count was $3.32 \log \mathrm{CFU} / \mathrm{mL}$ and total lactic acid bacterial count $3.96 \log \mathrm{CFU} / \mathrm{mL}$ at the beginning of Kanji fermentation. The LAB viable count reached a maximum (8.33 $\log \mathrm{CFU} / \mathrm{mL}$ ), thereafter slightly declined to $8.15 \log \mathrm{CFU} / \mathrm{mL}$ after 20 days. These high LAB counts in the Kanji could be due to nutrient-rich Black carrots. Similarly, high levels of LAB counts between 7.1 and 8.90 $\log$ CFU g ${ }^{-1}$ were reported (Tanguler and Erten 2012). Instead of the classical stationary phase after maximum growth, LAB decreased during storage. The lactic acid bacterial count was recorded $5.82 \log \mathrm{CFU} / \mathrm{mL}$ at the end of six months which was a little lesser than the minimum value recommended of $10^{6} \mathrm{cfu} / \mathrm{mL}$ of viable cells for probiotic products. The cell viability of lactic acid bacteria is decisive for the stability and quality of the fermented product. 


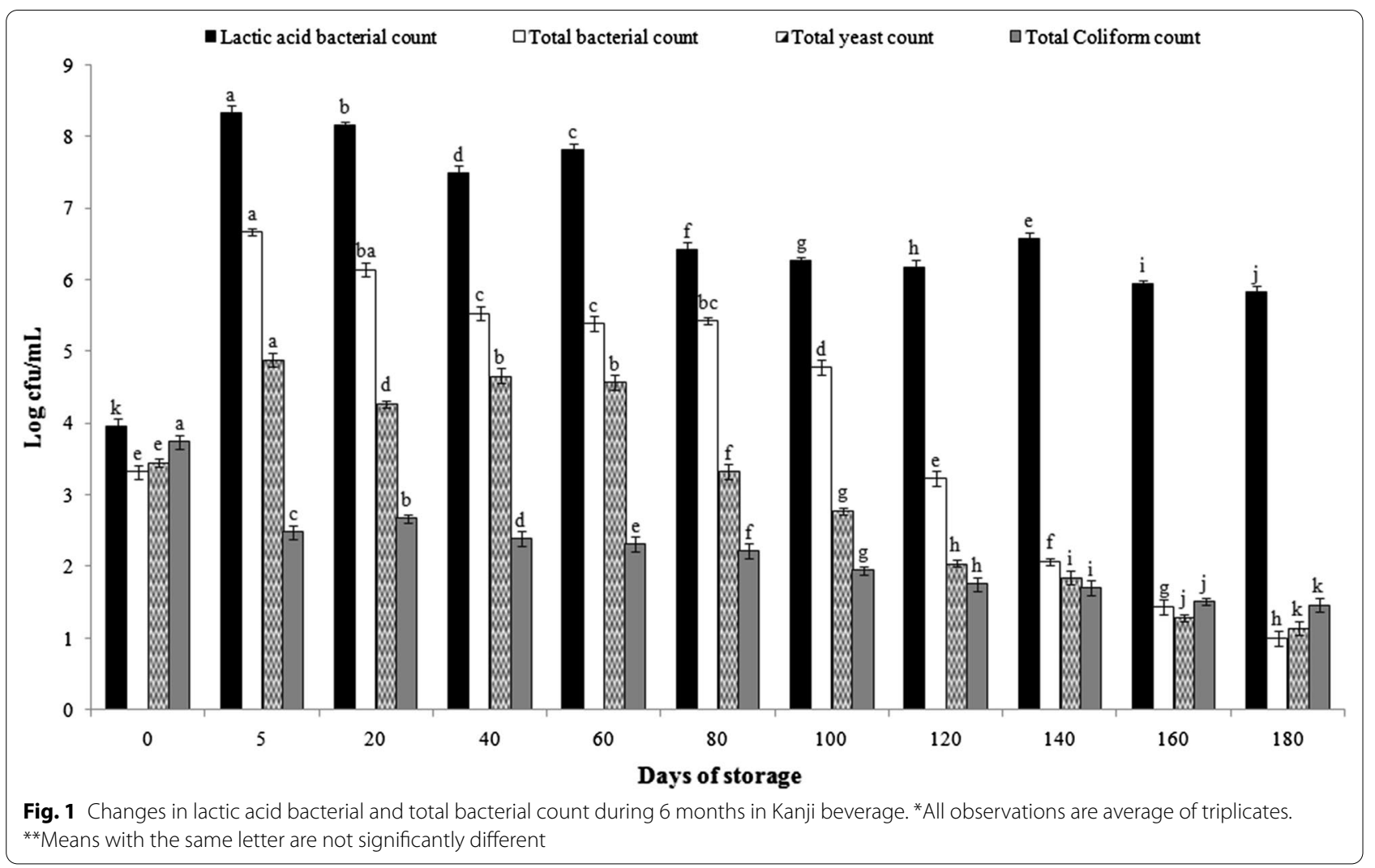

\section{Biochemical and genotypic characterization of bacterial isolates}

Initially, 11 bacterial strains were selected from the Kanji beverage based on morphological and biochemical characterization and were preserved at $4{ }^{\circ} \mathrm{C}$. These inherent cultures are autochthonous in the Kanji beverage and survive without the need for any supplement or nutrient. Out of these 11, seven isolates were labeled as PAU1, PAU3, PAU4, PA5, PAU7, PAU9, and PAU11 and were morphologically and biochemically characterized as shown in Table 1. Bacterial isolate PAU11 was genotypically identified as Pediococcus acidilactici and was submitted to the Genbank, NCBI database with accession number MK028218. Isolation of Pediococcus sp. in the black carrot beverage Shalgam was reported (Tangüler and Erten 2013) but no published data is found on the isolation of Pediococcus acidilactici from black carrot beverage.

\section{Physicochemical analysis of fermented Kanji Analysis of $\mathrm{pH}, \mathrm{TA}, \mathrm{TSS}$, and sugar content}

$\mathrm{pH}, \mathrm{TA}$, TSS, and sugar content of the Kanji beverage are shown in Table 2. There was a significant reduction in the $\mathrm{pH}$ and an increase in TA. The initial $\mathrm{pH} 6$ and TA $0.21 \%$ were recorded 3.47 and $0.99 \%$ were recorded after fermentation. Reduced $\mathrm{pH}$ and increased TA are of immense importance to the quality of the beverage (Viander et al. 2003). $\mathrm{pH}$ and TA range was recorded $3.47-3.78$ and $0.98-1.08 \%$ during the storage period of 180 days. These results were in good agreement with the findings of the traditionally fermented Shalgam beverage (Tanguler and Erten 2012). Reduced pH and high TA recorded during the storage could be contributing factors for the shelf stability of the Kanji beverage.

Initial TSS 6.5 reduced to 3 after 5 days of natural fermentation. Throughout the storage, it remained in the range 2.8-3.2. Total sugars and reducing sugars were recorded 78.21 and $39.79 \mathrm{mg} / \mathrm{mL}$ initially and reduced significantly to 36.32 and $27.16 \mathrm{mg} / \mathrm{mL}$ after natural fermentation. However, these residual sugars were present in the Kanji during storage. Total sugars and reducing sugars were recorded 38.84 and $26 \mathrm{mg} / \mathrm{mL}$ after six months of storage.

\section{Analysis of flavonoid and phenol content}

Phenolics and flavonoids, the secondary metabolites, occur throughout the plant kingdom. Phenols have an antioxidative effect by interacting with phenol ring and its resonance stabilization effect (Panghal et al. 2017) and flavonoids are available mostly in complexed forms such as o-glycosidic with several sugars such as glucose, galactose, arabinose, rhamnose, rutinose, and xylose. The 
Table 1 Morphological and biochemical characterization of bacterial isolates

\begin{tabular}{|c|c|c|c|c|c|c|c|}
\hline & PAU1 & PAU3 & PAU4 & PAU5 & PAU7 & PAU9 & PAU11 \\
\hline Gram reaction & $\begin{array}{l}+ \\
\text { Long rods }\end{array}$ & $\begin{array}{l}+ \\
\text { Rods }\end{array}$ & $\begin{array}{l}+ \\
\text { Cocci in pairs }\end{array}$ & $\overline{\text { Short rods }}$ & $\overline{\text { Short rods }}$ & $\overline{\text { Cocci }}$ & $\begin{array}{l}+ \\
\text { Cocci }\end{array}$ \\
\hline Colony characteristic & $\begin{array}{l}\text { Large, wrin- } \\
\text { kled, cream- } \\
\text { ish, oval }\end{array}$ & $\begin{array}{l}\text { Creamish, } \\
\text { irregular } \\
\text { and slimy }\end{array}$ & $\begin{array}{l}\text { Small, colorless and } \\
\text { chalk }\end{array}$ & $\begin{array}{l}\text { Yellow pig- } \\
\text { mented, } \\
\text { round }\end{array}$ & Raised, white, mucoid & $\begin{array}{l}\text { Small, color- } \\
\text { less and } \\
\text { pinpointed }\end{array}$ & $\begin{array}{l}\text { Small, } \\
\text { white } \\
\text { and } \\
\text { round }\end{array}$ \\
\hline
\end{tabular}

Biochemical characteristics

Sugar fermentation

$\begin{array}{ll}\text { Maltose } & + \\ \text { Lactose } & + \\ \text { Galactose } & + \\ \text { Raffinose } & + \\ \text { Cellobiose } & + \\ \text { Mannose } & + \\ \text { Trehalose } & + \\ \text { Citrate utilization } & + \\ \text { Triple Sugar Iron (TSI) } & + \text { A } \\ \quad \text { agar } & - \text { G } \\ \text { Nitrate reduction } & - \\ \text { Esculin hydrolysis } & + \\ \text { Urease } & - \\ \text { ONPG } & -\end{array}$

$\begin{array}{ll}+ & + \\ + & + \\ + & + \\ + & + \\ + & + \\ + & + \\ + & + \\ + & + \\ +A & +\mathrm{A} \\ -\mathrm{G} & -\mathrm{G} \\ - & - \\ + & + \\ - & - \\ + & -\end{array}$

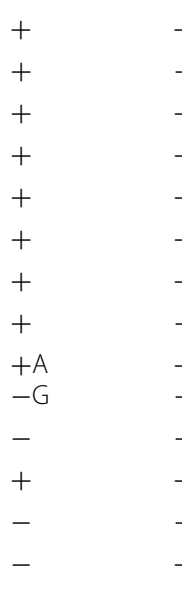

PAU (in isolate name) used as a label and signifies Punjab Agricultural University

Table 2 Effect of storage on the physicochemical parameters of the naturally fermented beverage

\begin{tabular}{|c|c|c|c|c|c|c|c|c|c|}
\hline $\begin{array}{l}\text { Days of } \\
\text { storage }\end{array}$ & $\mathrm{pH}$ & TSS ( $\left.{ }^{\circ} B r i x\right)$ & $\%$ TA & $\begin{array}{l}\text { Total sugars } \\
(\mathrm{mg} / \mathrm{mL})\end{array}$ & $\begin{array}{l}\text { Reducing } \\
\text { sugars }(\mathrm{mg} / \mathrm{mL})\end{array}$ & $\begin{array}{l}\text { \%Antioxidant } \\
\text { capacity }\end{array}$ & $\begin{array}{l}\text { Flavonoids } \\
\text { (mg/mL) }\end{array}$ & $\begin{array}{l}\text { Phenols (mg/ } \\
\mathrm{mL})\end{array}$ & $\begin{array}{l}\text { Ascorbic acid } \\
(\mathrm{mg} / 100 \mathrm{~mL})\end{array}$ \\
\hline 0 & $6 \pm .0 .02^{a}$ & $6.5 \pm 0.02^{\mathrm{a}}$ & $0.21 \pm 0.05^{b}$ & $78.21 \pm 0.2^{a}$ & $39.79 \pm 0.02^{a}$ & $70.75 \pm 0.03^{a}$ & $33.2 \pm 0.01^{a}$ & $33.5 \pm 0.01^{f}$ & $94 \pm 0.02^{b a}$ \\
\hline 5 & $3.47 \pm 0.01^{h}$ & $3 \pm 0.05^{c}$ & $0.99 \pm 0.02^{\mathrm{a}}$ & $36.32 \pm 0.1^{e}$ & $27.16 \pm 0.01^{\mathrm{cb}}$ & $79.96 \pm 0.02^{\mathrm{a}}$ & $38.14 \pm 0.02^{\mathrm{a}}$ & $40.8 \pm 0.02^{\mathrm{a}}$ & $110 \pm 0.03^{\mathrm{a}}$ \\
\hline 20 & $3.49 \pm 0.01^{\mathrm{hg}}$ & $2.8 \pm 0.02^{d}$ & $0.98 \pm 0.01^{\mathrm{a}}$ & $36.11 \pm 0.2^{e}$ & $26.21 \pm 0.02^{\mathrm{cd}}$ & $82.46 \pm 0.01^{a}$ & $40.02 \pm 0.01^{\mathrm{a}}$ & $39.8 \pm 0.02^{\text {ba }}$ & $110 \pm 0.02^{\mathrm{a}}$ \\
\hline 40 & $3.51 \pm 0.02^{9}$ & $3 \pm 0.02^{c}$ & $1.04 \pm 0.02^{\mathrm{a}}$ & $36.16 \pm 0.05^{e}$ & $26.95 \pm 0.02^{\mathrm{cb}}$ & $80.79 \pm 0.01^{\mathrm{a}}$ & $36.87 \pm 0.02^{\mathrm{a}}$ & $39.7 \pm 0.02^{\mathrm{bac}}$ & $108 \pm 0.01^{\mathrm{a}}$ \\
\hline 60 & $3.62 \pm 0.01^{f}$ & $2.8 \pm 0.03^{d}$ & $1.05 \pm 0.02^{\mathrm{a}}$ & $36.37 \pm 0.1^{e}$ & $27.47 \pm 0.02^{c b}$ & $79.98 \pm 0.005^{\mathrm{a}}$ & $36.72 \pm 0.02^{\mathrm{a}}$ & $38.8 \pm 0.02^{b d c}$ & $102 \pm 0.02^{\mathrm{ba}}$ \\
\hline 80 & $3.71 \pm 0.01^{e}$ & $3 \pm 0.02^{c}$ & $1.06 \pm 0.02^{\mathrm{a}}$ & $37.89 \pm 0.2^{d}$ & $27.89 \pm 0.02^{b}$ & $77.56 \pm 0.02^{\mathrm{a}}$ & $36.23 \pm 0.02^{\mathrm{a}}$ & $38.2 \pm 0.01^{\mathrm{edc}}$ & $97 \pm 0.01^{\text {ba }}$ \\
\hline 100 & $3.75 \pm 0.01^{d}$ & $2.8 \pm 0.02^{d}$ & $1.04 \pm 0.02^{\mathrm{a}}$ & $38.05 \pm 0.02^{\mathrm{cd}}$ & $26.95 \pm 0.01^{\mathrm{cb}}$ & $76.15 \pm 0.02^{\mathrm{a}}$ & $35.04 \pm 0.02^{\mathrm{a}}$ & $38.4 \pm 0.02^{\text {bedc }}$ & $88 \pm 0.005^{\mathrm{bac}}$ \\
\hline 120 & $3.76 \pm 0.01^{\mathrm{cd}}$ & $3 \pm 0.02^{c}$ & $1.05 \pm 0.01^{\mathrm{a}}$ & $38.53 \pm 0.2^{\mathrm{cb}}$ & $26.11 \pm 0.02^{d}$ & $74.31 \pm 0.02^{\mathrm{a}}$ & $35.78 \pm 0.02^{a}$ & $38.7 \pm 0.03^{e d}$ & $85 \pm 0.03^{c}$ \\
\hline 140 & $3.79 \pm 0.01^{b}$ & $2.8 \pm 0.02^{d}$ & $1.07 \pm 0.02^{\mathrm{a}}$ & $38.66 \pm 0.1^{b}$ & $26.63 \pm 0.01^{\mathrm{cbd}}$ & $73.81 \pm 0.02^{\mathrm{a}}$ & $35.87 \pm 0.02^{\mathrm{a}}$ & $37.9 \pm 0.02^{\mathrm{ed}}$ & $83 \pm 0.05^{b c}$ \\
\hline 160 & $3.78 \pm 0.02^{\mathrm{cb}}$ & $3.2 \pm 0.02^{b}$ & $1.08 \pm 0.01^{\mathrm{a}}$ & $38.84 \pm 0.1^{b}$ & $26.49 \pm 0.02^{\mathrm{cbd}}$ & $73.24 \pm 0.02^{\mathrm{a}}$ & $34.07 \pm 0.01^{\mathrm{a}}$ & $37.7 \pm 0.005^{\mathrm{ed}}$ & $80 \pm 0.01^{b c}$ \\
\hline 180 & $3.78 \pm 0.01^{c b}$ & $3.2 \pm 0.01^{b}$ & $1.06 \pm 0.03^{\mathrm{a}}$ & $38.84 \pm 0.2^{b}$ & $26 \pm 0.2^{c d}$ & $72.78 \pm 0.01^{\mathrm{a}}$ & $34.04 \pm 0.01^{\mathrm{a}}$ & $37.07 \pm 0.02^{\mathrm{e}}$ & $80 \pm 0.02^{b c}$ \\
\hline
\end{tabular}

TA titrable acidity, TSS total soluble solids

All observations are average of triplicates

Means with the same letter are not significantly different

levels of phenolics and flavonoids in the Kanji tested were significantly higher $40.8 \mathrm{mg} / \mathrm{mL}$ and $38.14 \mathrm{mg} / \mathrm{mL}$ in contrast to $33.5 \mathrm{mg} / \mathrm{mL}$ and $33.2 \mathrm{mg} / \mathrm{mL}$ of unfermented preparation (Table 2). This increase could be due to the enzymatic action and acid production of the strains facilitating the release of flavonoids and phenols from their complex form into more soluble free form Katina et al. (2007). At 3-month interval, phenolics and flavonoids were recorded 38.8 and $36.72 \mathrm{mg} / \mathrm{mL}$ and were 37.07 and $34.04 \mathrm{mg} / \mathrm{mL}$ after 6 months of storage. The phenolic and flavonoid content was higher than the unfermented preparation throughout the storage period. 


\section{\% Antioxidant capacity}

1, 1-Diphenyl-2-picryl hydrazyl (DPPH) antioxidant activity was measured in terms of percentage scavenging of a pre-formed free-radical by antioxidants in the samples. The antioxidant capacity of kanji increased after fermentation and was found $79.96 \%$ in Kanji (Table 2). This can be associated with the presence of phytochemicals like flavonoids and phenolics in Kanji which are an excellent source of antioxidants (Kikuzaki et al. 2002). The highest $82.46 \%$ antioxidant capacity was recorded at 20 days of storage. In a previous study, Haria fermented with L. fermentum KKL1 also showed a strong 82.54\% antioxidant capacity against DPPH (Ghosh et al. 2015).

\section{Ascorbic acid content}

The ascorbic acid content of traditionally fermented Kanji is shown in Table 2. The ascorbic acid content of the unfermented beverage recorded was $90 \mathrm{mg} / 100 \mathrm{~mL}$. A significant increase to $100 \mathrm{mg} / 100 \mathrm{~mL}$ was recorded after fermentation which was stable up to the 40th day of storage, thereafter, gradually reduced. At the end of 6 months, ascorbic acid was recorded $80 \mathrm{mg} / 100 \mathrm{~mL}$ in the fermented Kanji. Reduction in ascorbic acid content during storage could be due to the oxidation activity of enzyme ascorbic acid oxidase by the collective effect of light and oxygen (Bhardwaj and Mukherjee 2011). Daily intake of ascorbic acid or vitamin $\mathrm{C}$ is, however, very popular nowadays. Appropriate doses of ascorbic acid (Vitamin-C) can be a preventive approach for the novel coronavirus, COVID-19 (Wang et al. 2020). Studies suggest that ascorbic acid may prevent the receptiveness of lower respiratory tract infection (Hemila 1997), while COVID-19 may cause lower respiratory tract infection.

\section{Discussion}

Based on the nutritive analysis, Kanji holds a promising alternative for dairy-based probiotics and act as a plant-based probiotic delivery vehicle. Carrot juice serves as a good dairy alternative growth medium for probiotic growth. Carrot juice constitutes of $2 \%(\mathrm{w} / \mathrm{v})$ sucrose, $1 \%(\mathrm{w} / \mathrm{v})$ glucose, and $0.8 \%(\mathrm{w} / \mathrm{v})$ fructose (Kun et al. 2008). Glucose and sucrose are the major sources of energy and carbon for the growth of lactic acid bacteria in carrot juice. Both L. rhamnosus and L. bulgaricus exhibited significant growth up to about $10^{9} \mathrm{cfu} / \mathrm{mL}$ at the end of fermentation in carrot juice (Nazzaro et al. 2008). However, there is no report of the previous occurrence of Pediococcus acidilactici in the Kanji fermentation. For probiotic preparations, there are yet not any fixed standards, nonetheless, the US FDA recommendation of the minimum probiotic count level is at least $10^{6} \mathrm{cfu} / \mathrm{mL}$ in a probiotic food. Taking into account the ingested amount and effect of various storage conditions on probiotic viability, $10^{8}-10^{9}$ probiotic microbial daily intake is crucial to achieve probiotic action in human (Knorr 1998). It has also been suggested that probiotics should be consumed on regular basis (approximate consumption: $100 \mathrm{~g}$ ) to be effective in delivering about $10 \mathrm{~g}$ viable cells into the instestine (Miller 1959). During the storage period of 60 days, the count reached approximately $10^{8} \mathrm{CFU} / \mathrm{mL}$ level which suggests exploring the probiotic potential of the strain. Yeast and Coliform count decreased in the Kanji beverage after fermentation. Low $\mathrm{pH}$ and the addition of condiments may result in the decrease of coliform and yeast count due to their antimicrobial properties (Madhu et al. 2010). Salt added in the juice does not exhibit antimicrobial activity, but it reduces the water activity in foods which results in the slowing down or interruption in the vital microbial processes and hence increases the shelf stability of a product. Salt serves as a preservative during the fermentation of fruits and vegetables. The Kanji beverage prepared was safe for consumption according to food standards (Food Safety and Standards Authority of India 2018).

The high viable cell counts suggest that carrot supplied sufficient nutrients for the multiplication for all the bacterial strains. Besides that the presence of phenolic compounds and antioxidants could have contributed for a higher survival through the creation of anaerobic conditions in ideal proportions that favored the multiplication of probiotic microflora (Lima et al. 2012). The high levels of the residual sugars in Kanji suggest the role of $\mathrm{pH}$ to stop the fermentation process contrary to the lack of carbohydrate substrate required and results were in agreement with study of Gardner et al. (2001) which reported dual utilization of glucose and fructose and high quantity of residual sugars as feature of LAB metabolism. Furthermore, the high antioxidant activity in the beverage resulted due to the increase in the phenols and flavonoids. The increase in flavonoids content may have resulted due to the increase in acidic metabolites during fermentation, which involves unchaining bound flavonoids components and converting them into available form Ademiluyi and Oboh (2011). In context to this, phenolic compounds in natural medium are associated with sugar, which decreases their availability. During fermentation process, proteases hydrolyze complexes of phenolics into soluble-free phenols and other simpler and biologically more active that can be readily absorbed (Ademiluyi and Oboh 2011). The evaluation of antioxidant activity in food products has an important role in the nutritional research as it provides constructive information regarding the functional quality of food material without the analysis of each antioxidant compound (Scalfi et al. 2000). 


\section{Conclusion}

Consumer demand for functional non-dairy-based products has been increased and probiotics are being incorporated to produce ready-to-serve drinks with plant-based origin. Despite their high nutritional content, black carrots (var. Punjab Black Beauty) are underutilized due to their short shelf life and flavor preference. Kanji serves as an alternative to exploit highly nutritive minimally processed black carrots providing health benefits to the consumer. The isolated lactic acid bacterial strain Pediococcus acidilactici possesses desirable probiotic properties and can serve as novel autochthonous starter cultures for fermentation studies to assess their technological characteristics. Pediococcus sp. has the functional property of bacteriocin production which can enhance the safety of the beverage prepared. The results obtained underlined that the presence of the tested probiotic strain in the fermented black carrot beverage was well supported. However, the probiotic delivery using food substrate often needs special technologies. Based on the present results, the development of bioprocess for microbiologically safe and controlled fermentation method with selective autochthonous functional starter cultures for production of a shelf-stable highly nutritive Kanji beverage is required. Moreover, the development of probiotic black carrot product helps to sustain the rural economy by the development of small-scale industries of agriculturists with minimal processing cost.

\section{Abbreviations \\ FSSAI: Food Safety and Standards Authority of India; FDA: Food and Drug Administration; LAB: Lactic acid bacteria; NCBI: National Centre for Biotech- nology Information; TA: Titrable acidity; TSS: Total soluble solids; PAU: Punjab Agricultural University.}

\section{Acknowledgements}

All authors are thankful to the Head of the Department, Microbiology, Punjab Agricultural University for providing appropriate support for this research.

\section{Authors' contributions}

CS has done the writing of the final manuscript. All authors contributed to the workplan and implementation of the research, analysis of results, and were in charge of overall direction and design. All the authors have read and approved the manuscript before submission.

\section{Funding}

This work was supported by the Department of Microbiology, Punjab Agricultural University, Ludhiana for the master's thesis of author CS.

\section{Availability of data and materials}

Not applicable.

\section{Declarations}

Ethical approval and consent to participation

No ethical approval and consent for participation were required for this study.

\section{Consent for publication}

All authors have provided their consent for this publication.

\section{Competing interests}

No competing interests are related to this study.

Received: 20 April 2021 Accepted: 16 July 2021

Published online: 10 August 2021

\section{References}

Ademiluyi AO, Oboh G (2011) Antioxidant properties of condiment produced from fermented bambara groundnut (Vigna subterranean L. Verdc). J Food Biochem 35:1145-1160

AOAC (1984) Official methods of analysis. Association of Official Analytical Chemists Inc., Arlington, p 391

AOVC (1996) Methods of vitamin assay. Association of vitamin chemist Inc (Ed.), Interscience. As J Food Ag-Ind 4:359-364

Bhardwaj RL, Mukherjee S (2011) Effects of fruit juice blending ratios on kinnow juice preservation at ambient storage condition. Afr J Food Sci 5:281-286

Brand-Williams W, Cuvellier ME, Berset C (1995) Use of a free radical method to evaluate antioxidant activity. LWT-Food Sci Technol 28:25-30

Chang C, Yang M, Wen H, Chern J (2002) Estimation of total flavonoid content in propolis by two complementary colorimetric methods. J Food Drug Anal 10:178-182

Dubois M, Gills KA, Hamilton JK, Roberts PA, Smith F (1956) Colorimetric method for determination of sugars and related substances. Anal Chem 28:350-356

Font de Valdez G, de Giori GS, Garro M, Mozzi F, Oliver G (1990) Lactic acid bacteria from naturally fermented vegetables. Microbiol Alim Nutr 8:175-179

Food Safety and Standards Authority of India (2018) Microbiological standards for fruits and vegetables and their products. The Gazette of India

Gardner NJ, Savard T, Obermeier P, Caldwell G, Champagne CP (2001) Selection and characterization of mixed starter cultures for lactic acid fermentation of carrot, cabbage, beet and onion vegetable mixtures. Int J Food Microbiol 64:261-275

Ghosh K, Ray M, Adak A, Dey P, Halder SK, Das A, Jana A, Parua S, Das Mohapatra PK, Pati BR, Mondal KC (2015) Microbial, saccharifying and antioxidant properties of an Indian rice based fermented beverage. Food Chem 168:196-202

Hemila H (1997) Vitamin C intake and susceptibility to pneumonia. Pediatr Infect Dis J 16:836-837

In't Veld JH, HavenaarMarteau RP (1994) Establishing a scientific basis for probiotic R\&D. Trends Biotechnol 12(1):6-8

Katina K, Laitila A, Juvonen R, Liukkonen KH, Kariluoto S, Piironen V, Landberg R, Aman P, Poutanen K (2007) Bran fermentation as a means to enhance technological properties and bioactivity of rye. Food Microbiol 24:175-186

Kikuzaki H, Hisamoto M, Hirose K, Akiyama K, Taniguchi H (2002) Antioxidant properties of ferulic acid and its related compounds. J Agric Food Chem 50:2161-2168

Kirca A, Ozkan M, Cemeroglu B (2006) Stability of black carrot anthocyanins in various fruit juices and nectars. Food Chem 97:598-605

Knorr D (1998) Technology aspects related to microorganisms in functional foods. Trends Food Sci Technol 31(8):295-306

Kun S, Rezessy-Szabo JM, Nguyen QD, Hoschke A (2008) Changes of microbial population and some components in carrot juice during fermentation with selected Bifidobacterium strains. Process Biochem 43:816-821

Lamba J, Goomer S, Saxena SK (2019) Study the lactic acid bacteria content in traditional fermented Indian drink: Kanji. Int J Gastro Food Sci 16:100143

Lima IFP, Lindner JD, Soccol VT, Parada JL, Soccol CR (2012) Development of an innovative nutraceutical fermented beverage from Herbal Mate (Ilex paraguariensis A. St.-Hil.) extract. Int J Mol Sci 12:788-800

Madhu AN, Giribhattanavar P, Narayan MS, Prapulla SG (2010) Probiotic lactic acid bacterium from kanjika as a potential source of vitamin B12: evidence from LC-MS, immunological and microbiological techniques. Biotechnol Lett 32(4):503-506

Miller GL (1959) Use of dinitrosalicylic acid reagent for determination of reducing sugar. Anal Chem 31:426-428

Nazzaro F, Fratianni F, Sada A, Orlando P (2008) Synbiotic potential of carrot juice supplemented with Lactobacillus spp. and inulin or fructooligosaccharides. J Sci Food Agric 88:2271-2276 
Panghal A, Virkar K, Kumar V, Dhull S B, Gat Y, Chhikara N (2017) Development of probiotic beetroot drink. Curr Res Nutr Food Sci J 5(3)

Perricone M, Bevilacqua A, Corbo MR, Sinigaglia M (2010) Use of Lactobacillus plantarum and glucose to control the fermentation of "Bella di cerignola" table olives, a traditional variety of Apulian region (southern Italy). J Food Sci 75:M430-M436

Reddy KB, Raghavendra P, Kumar BG, Misra MC, Prapulla SG (2007) Screening of probiotic properties of lactic acid bacteria isolated from Kanjika, an ayurvedic lactic acid fermented product: an in-vitro evaluation. J Gen Appl Microbiol 53(3):207-213

Rice-Evans C, Miller N, Paganga G (1997) Antioxidant properties of phenolic compounds. Trends Plant Sci 2:152-159

Scalfi L, Fogliano V, Pentagelo A, Graziani G, Giordano I, Ritieni A (2000) Antioxidant activity and general fruit characteristics in different ecotypes of Corbarini small tomatoes. J Agric Food Chem 48:1363-1366

Schubert M, Fink S, Schwarze FWMR (2008) Field experiments to evaluate the application of Trichoderma strain (t-15603.1) for biological control of wood decay fungi in trees. Arboric J 31:249-268

Slinkard K, Singleton VL (1977) Total phenol analysis: automation and comparison with manual methods. Am J Enol Vitic 28:49-55
Soccol CR, de Souza-Vandenberghe LP, Spier MR, Pedroni-Mederios AB, Yamaguishi CT (2010) The potential of probiotics: a review. Food Technol Biotechnol 48:413-434

Tanguler H, Erten H (2012) Chemical and microbiological characteristics of shalgam (salgam): a traditional Turkish lactic acid fermented beverage. J Food Qual 35:298-306

Tangüler H, Erten H (2013) Selection of potential autochthonous starter cultures from shalgam, a traditional Turkish lactic acid-fermented beverage. Turk J Agric for 37(2):212-220

Viander B, Maki M, Palva A (2003) Impact of low salt concentration, salt quality on natural large scale sauerkraut fermentation. Food Microbiol 20:391-395

Wang L, Wang Y, Ye D, Liu Q (2020) Review of the 2019 novel coronavirus (SARS-CoV-2) based on current evidence. Int J Antimicrob Agents $55: 105948$

\section{Publisher's Note}

Springer Nature remains neutral with regard to jurisdictional claims in published maps and institutional affiliations.

\section{Submit your manuscript to a SpringerOpen ${ }^{\circ}$ journal and benefit from:}

- Convenient online submission

- Rigorous peer review

- Open access: articles freely available online

- High visibility within the field

- Retaining the copyright to your article

Submit your next manuscript at $\gg$ springeropen.com 